\title{
Success and failure in Cenozoic global correlations using golden spikes: A geochemical and magnetostratigraphic perspective
}

\author{
${ }^{1}$ Department of Earth and Planetary Sciences and Institute for Earth, Oceans, and Atmospheric Sciences, 610 Taylor Rd., Rutgers University, \\ Piscataway, New Jersey 08854, USA; *Corresponding author, E-mail: kgm@rci.rutgers.edu
}

(Received: June 4, 2016; Revised accepted: December 11, 2016)

http://dx.doi.org/10.18814/epiiugs/2017/v40i1/017003

We review examples of placement of select Cenozoic Global Boundary Stratotype Sections and Points (GSSP = "golden spikes") from a geochemical and magnetostratigraphic perspective. Though biostratigraphy is the sine qua non for placing modern chronologic tools (high-resolution radiometric dates, magnetochronology, and astrochronology) into proper stratigraphic context, its use as the primary correlation tool for GSSP is less desirable than using magnetostratigraphic or chemostratigraphic markers. Here, we advocate for defining of GSSP s at lithologic levels that are globally correlatable using magnetic reversals and/or abrupt geochemical changes, and the avoidance of biostratigraphic datum levels (that are necessarily biogeographically restricted) as primary criterion for correlation. We provide two examples where placement of golden spikes in association with global geochemical events has been successful: the Cretaceous/Paleogene (K/ $\mathrm{Pg}$ ) and Paleocene/Eocene boundaries. We discuss three boundaries where placement of the GSSP is unfortunately not at distinct isotopic or magnetostratigraphic events (the Eocene/Oligocene, Oligocene/Miocene, and Pliocene/ Pleistocene (= Neogene/Quaternary) boundaries. Lectostratotypes for isotopic reference are proposed for the Eocene/Oligocene boundary at South Atlantic Site 522 and for the Oligocene/Miocene boundary at Southern Ocean Site 1090.

\section{Introduction}

The implementation of numerous Global Boundary Stratotype Sections and Points (GSSPs) by the International Stratigraphic Subcommission (http://www.stratigraphy.org/index.php/ics-gssps) has provided improved stability to the delineation of time and chronostratigraphic (time-rock) units. GSSPs are "...the designated type of a stratigraphic boundary identified in published form and marked in the section as a specific point in a specific sequence ${ }^{1}$ of rock strata and constituting the standard for the definition and recognition of the stratigraphic boundary between two named global standard stratigraphic (chronostratigraphic) units." (Cowie et al., 1986, p. 5). GSSPs are "golden spikes" that build on the boundary stratotype concept of the International Stratigraphic Guide (Hedberg, 1976; Salvador, 1994), though GSSPs differ somewhat from boundary stratotypes as discussed by Aubry (2007). Most of the stages/ages (excepting the Lutetian, Bartonian, Priabonian, Burdigalian, and Langhian Stages) and all of the series/ epoch boundaries of the Cenozoic have GSSPs. These "golden spikes" are placed in the stratigraphic record in outcrops or boreholes at a given level. The level of a GSSP is chosen based on the availability of various criteria (biostratigraphic, chemostratigraphic, or magnetostratigraphic) and the stability and accessibility of the stratotype to correlate sections elsewhere to the GSSP. These criteria do not define the boundaries; rather the placement at a given lithologic level is guided by the availability of a means to correlate from the GSSP. There are challenges in correlating GSSPs and other reference sections especially over long distances or between marine and terrestrial sections, in part because no two sections are alike (e.g., Aubry, 1995).

We suggest that stable isotopic shifts $\left(\delta^{18} \mathrm{O}, \delta^{13} \mathrm{C}\right.$ in marine carbonates and terrestrial paleosols/bones/teeth), other rapid geochemical changes (e.g., extraterrestrial Ir), and magnetostratigraphy provide the best means of correlating GSSPs globally. We have previously noted that stable isotopes $\left(\delta^{18} \mathrm{O}, \delta^{13} \mathrm{C}\right)$ not only provide for Quaternary correlations (e.g., Lisiecki and Raymo, 2005), but also Paleogene and Neogene correlations (e.g., Mi and Oi events; Miller et al., 1991; Wright and Miller, 1992). Here, we briefly examine successes and failures in placement of select Cenozoic GSSPs. Some of the GSSPs are directly associated with geochemical or paleomagnetic events, but others are more remotely associated, leading to uncertain correlation. We review the Cretaceous/Paleogene, Paleocene/Eocene, Eocene/Oligocene, Oligocene/Miocene, and Neogene/Quaternary boundaries, focusing on the relationships between geochemical $\left(\delta^{18} \mathrm{O}, \delta^{13} \mathrm{C}\right.$, and platinum group elements PGEs) and magnetostratigraphic records.

We suggest that the term "succession" is more appropriate and that the term "sequence" be restricted to an unconformity bounded unit or "Stratigraphic unit of composed of a relatively conformable succession of genetically related strata and bounded at its top and base by unconformities or their correlative conformities." Mitchum et al. (1977) 


\section{The Cretaceous/Paleogene (K/Pg) boundary}

Marking the boundary between the Mesozoic and Cenozoic Eras, the $\mathrm{K} / \mathrm{Pg}$ Boundary excites the imagination of scientists and public alike because it marks a major mass extinction event that includes non-avian dinosaurs, marine and flying reptiles, ammonites, rudists, and marine calcareous plankton (e.g., Luterbacher and Premoli-Silva, 1964; Raup and Sepkoski, 1982). K/Pg boundary sections have long been interpreted as disconformable, though continuity has been demonstrated in many sections and apparent hiatuses in many in pelagic sections attributable to major reductions in Danian sedimentation rates due to decreased pelagic flux (e.g., Esmeray-Senlet et al., 2016). The section at Gubbio, Italy figured prominently in identification of the mass extinction, where greater than $90 \%$ of planktonic foraminiferal species disappear at a knife's edge at the base of a distinct clay (Luterbacher and Premoli-Silva, 1964). Paleomagnetic study of this section showed that the extinctions occurred in Chron C29r (Alvarez et al., 1977), constraining the extinction to an interval less than $\sim 0.5 \mathrm{Myr}$ (Kent, 1977). Seeking further constraints on the rapidity of the extinction prompted Alvarez et al. (1980) to measure Ir across the boundary at Gubbio and Stevns Klint, Denmark, hoping to interpret changes in Ir concentration in the clay as a proxy for sedimentation rate. Instead, they found a remarkable enrichment of $\sim 9$ parts per billion (ppb) at the precise level of the mass extinction of marine plankton, leading to the hypothesis that a large $(8-10 \mathrm{~km})$ bolide impacted the Earth, triggering a mass extinction. Identification of the Ir anomaly globally (include terrestrial sections), shocked quartz, impact spherules, and ultimately the impact crater at Chicxulub, Mexico (see summary in Schulte et al., 2010) has linked the Ir and mass extinction. The Deccan Traps likely played a role in the degradation of environments in the last $0.5 \mathrm{Myr}$ of the Cretaceous (e.g., Olsson et al., 2002; Keller et al., 2010) and the largest outpouring of basalt may have been triggered by the impact (Richards et al., 2015). However, the marine extinctions are directly linked to the Ir brought to Earth by a chondrite (e.g., Alvarez et al., 1977; Olsson et al., 1997).

In seeking a boundary stratotype, the International Commission on Stratigraphy (ICS) voted to place the GSSP at the base of a clay at El Kef, Tunisia (Cowie et al., 1989), noting that it lacked magnetostratigraphy and macrofossils, but did contain a record of Ir at the base of a $\sim 50 \mathrm{~cm}$ thick clay (Fig. 1). Though established by vote in 1989, details of the section were not synthesized until Molina et al. (2006) (Fig. 1) compiled data from the section, including an Ir profile (Robin and Rocchia, 1998), a large (>2.5\%) decrease in $\delta^{13} \mathrm{C}$ in bulk carbonate (Keller and Lindinger, 1996), and a dramatic turnover in planktonic foraminifera (Arenillas et al., 2006). It should be noted that any of the events (Ir anomaly, $\delta^{13} \mathrm{C}$ decrease, or extinction of marine plankton) could potentially be used to correlate the $\mathrm{K} / \mathrm{Pg}$. Of these, Ir provides the best marker since it is global, representing primarily stratospheric fallout occurring on the scale of several years (Toon et al., 1982). Ir and other Platinum Group Elements (PGEs) clearly demonstrate an extraterrestrial source and identify the impactor as a chondrite (Kyte et al., 1985). Dating of impact glasses found with the Ir clearly ties the glasses to the Chicxulub crater (Swisher et al., 2002; Renne et al., 2013).

The $\delta^{13} \mathrm{C}$ change in bulk carbonate appears to be exaggerated by the extinction of the calcareous nannofossils that dominate the bulk signal (Alegret and Thomas, 2009; Alegret and Thomas, 2012). Monospecific $\delta^{13} \mathrm{C}$ analyses of Heterohelix globulosus suggest the surface change in seawater $\delta^{13} \mathrm{C}$ was closer to $1 \%$ o (Esmeray-Senlet et al., 2015). Nevertheless, the carbon isotopic change is recorded in terrestrial sections (Arens and Jahren, 2000) and thus can be used to correlate marine and non-marine sections.

The paleontological record of the extinction event may be blurred due to reworking, especially in proximal sections close to Chicxulub (Schulte et al., 2010) and marine to non-marine correlations are not possible with marine plankton. Keller et al. (2002) have reported gradual or stepped extinctions and apparent multiple spherule layers in proximal sections that reflect reworking by a megatsunami. Slow Danian sedimentation rates and the nature of the gap zones (e.g., earliest Danian Zone P0 is from the extinction of Cretaceous foraminifera to the lowest occurrence of Parvularugoglobigerina eugubina) add to complications from reworking.

The K/Pg boundary is not "defined" by the mass extinction or the Ir anomaly. Rather, various authors have used the mass extinction and/ or the Ir anomaly to correlate local sections to El Kef, often with quite different results (cf. Schulte et al., 2010 with Keller et al., 2010). Nevertheless, the boundary stratotype provides the reference for framing such debates about correlation, though it should be noted that current political uncertainty in Tunisia has made the K/Pg boundary stratotype difficult to access.

Ir provides potentially the best global means of correlating the $\mathrm{K} / \mathrm{Pg}$ boundary, but its distribution can be complicated by migration and bioturbation. Though relatively immobile, Ir can migrate in sediments and be re-concentrated at redox boundaries (Colodner et al., 2002). Bioturbation potentially blurs the Ir deposited in a matter of years over 10's cm to even meters of section (Fig. 1; Sawlowicz, 1993; Claeys et al., 2002; Hull et al., 2011; Esmeray-Senlet, 2015; Esmeray-Senlet et al., 2017).

The K/Pg boundary in New Jersey provides examples of Ir movement and bioturbation. Onshore drilling by Ocean Drilling Program Leg 174AX at Bass River, NJ recovered a 6-cm thick spherule bed containing shocked quartz and carbonate accretionary lapilli (Fig. 1; Olsson et al., 1997, 2002; Yancey and Guillemette, 2008). Strata below the boundary are assigned to the uppermost Maastrichtian based on nannofossil, dinocyst, and foraminiferal biostratigraphy. The extinction of Cretaceous planktonic foraminifera occurs at the base of the spherule bed, with in situ glauconite clays, Danian Zone P0, and a Cretaceous rip-up clast above the spherule bed. Ir shows a distinct 2 $\mathrm{ppb}$ at the base of the spherule bed and secondary peak of $\sim 0.5 \mathrm{ppb}$ above it. In this case, the Ir deposited following the ballistic ejecta of the spherules has clearly migrated to the base of the bed (Olsson et al., 1997; Miller et al., 2010).

In other New Jersey sections, the Ir anomaly is associated with markers for the boundary. For example at Buck Pit and Meirs Farm, Ir peaks $5 \mathrm{~cm}$ below the lowest occurrence of the Danian marker $S$. inornata (Fig. 1; Miller et al., 2010; Vellekoop et al., 2016). Modeling of bioturbation at these and other $\mathrm{NJ}$ sites show that the relatively low Ir $(0.5 \mathrm{ppb})$ at these sites can be explained by bioturbation of Ir over 10 $110 \mathrm{~cm}$, blurring the signal but with the same source function as the larger anomaly at Bass River (Esmeray-Senlet, 2015; Esmeray-Senlet et al., 2017). The study at Bass River demonstrates that identifica- 


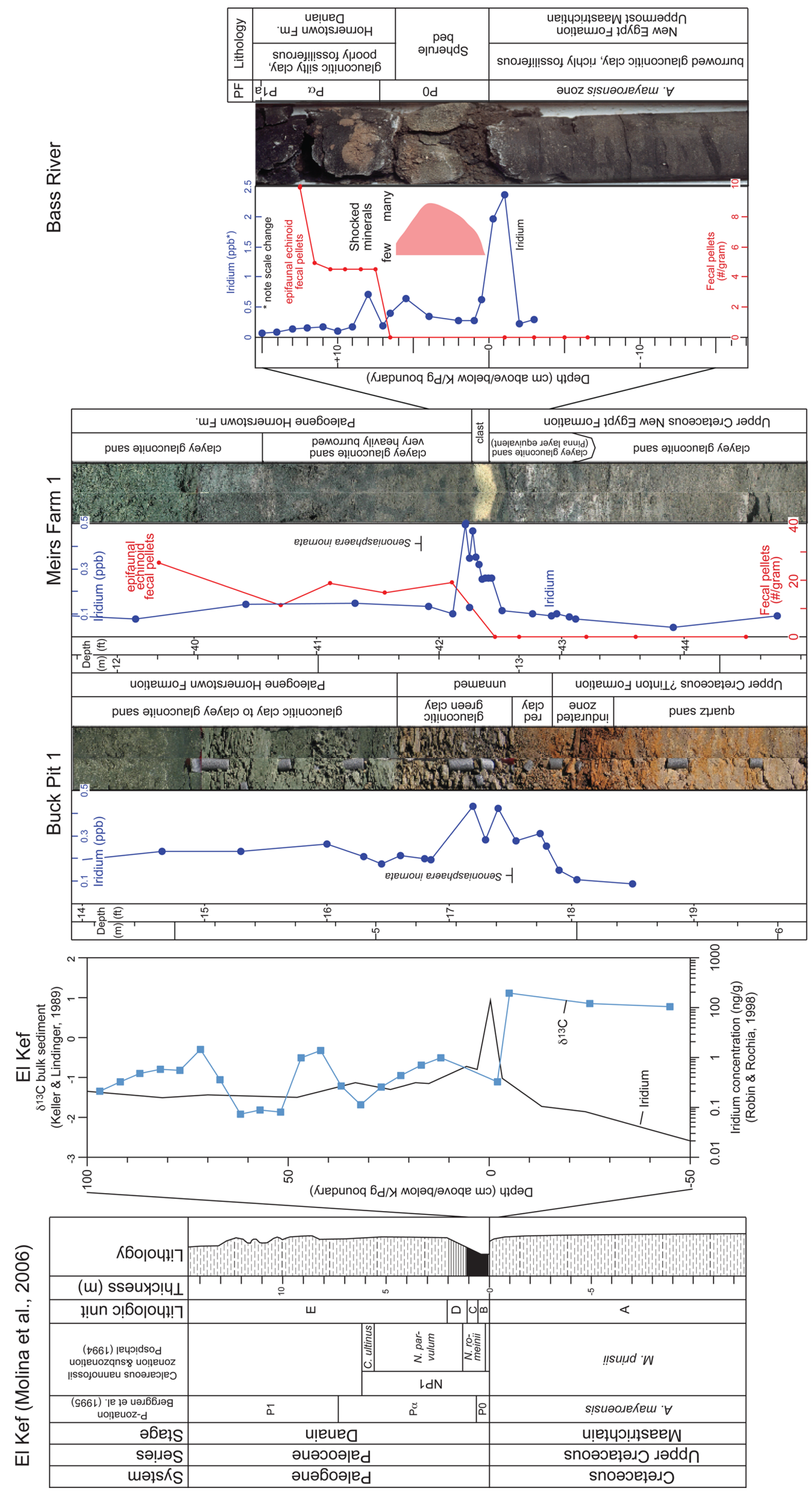


tion of an Ir anomaly does not guarantee precise correlation to the Ir at the GSSP.

Controversy exists over other correlations of New Jersey sections with the GSSP using Ir. Landman et al. (2007) reported an Ir anomaly at the base of a $20-\mathrm{cm}$ thick Pinna layer containing the uppermost Cretaceous ammonite Discoscaphites iris in outcrops at Tighe Park, NJ. They suggested that the Ir could be used to correlate to the GSSP and thus the ammonites and associated fauna lived on into the Danian. Miller et al. (2010) validated the Ir in cores from Tighe Park, but interpreted that the Ir had migrated down $20 \mathrm{~cm}$, even as it had migrated at Bass River. However, Ebel et al. (2015) reported shocked quartz and enrichment of spinel and $\mathrm{Ni}$ at the base of the Pinna bed, arguing that the Ir is in situ. This interesting conundrum remains unresolved though it does appear possible that the fauna in the Pinna bed lived on after the impact and highlights that no correlation tool is perfect.

Correlation of marine and non-marine sections has been possible using Iridium. The extinctions occurred during Chron C29r in both realms, and there is an Ir enrichment in the lower $\mathrm{Z}$ coal in Montana (e.g., Sprain et al., 2014). Though it has been suggested that the Ir was not in situ in terrestrial sections, recent high-resolution radiometric dates validate correlations first made using Ir (e.g., Sprain et al., 2014).

The placement of the K/Pg GSSP at El Kef is unfortunate because it is difficult to visit now due to political instability in Tunisia. In such cases, new GSSPs can be designated, honoring the physical placement in the original stratotype as much as possible. It is also possible to place lectostratotypes or new holostratotypes in coreholes (e.g., the base of the Holocene placed in the NGRIP ice core; Walker et al., 2008), with the realization that material available is necessarily limited. Lectostratotypes are stratotypes for previously described holostratotypes that are "...subsequently designated in the absence of an adequately designated original stratotype (holostratotype)" (Salvador, 1994, p 28). The Zumaia, Spain K/Pg section was not selected as the GSSP because of potential complications due to tectonism (Cowie et al., 1989), even though the Thanetian and Selandian GSSP have been placed there (Molina et al., 2006; Schmitz et al., 2011). The Zumaia section may warrant further examination as the K/Pg holostratotype if access to El Kef remains hazardous to access.

\section{The Paleocene/Eocene (P/E) boundary}

The P/E boundary was originally associated with the base of the Ypresian Stage (Aubry, 1988; Berggren, 2007). The P/E boundary was correlated with planktonic foraminifera (base Zone P6a of Berggren et al. (1995) = Zone E3 of Wade et al., 2011) or nannofossils (base of Zone NP10; Aubry, 1998), with the latter being $\sim 0.8$ Myr older on the current Geologic Time Scale (GTS2012; Gradstein et al., 2012). Kennett and Stott (1991) first recognized a large negative (2.5 to 4\%) carbon isotopic excursion (CIE) and attendant $\delta^{18} \mathrm{O}$ decrease and warming in benthic and planktonic foraminifera at Maud Rise Site 690 (Fig. 2) that was dubbed the Late Paleocene Thermal Maximum (Zachos et al., 1993; see summary of PETM/CIE in McInerney and Wing, 2011). Prompted by the importance of these events, the Working Group (WG) on the Paleocene/Eocene boundary decided to locate the P/E GSSP at level $1.57 \mathrm{~m}$ in the Dababiya Quarry, Egypt (Aubry et al., 2007). This level was chosen in part because the initiation of a major $\delta^{13} \mathrm{C}$ decrease in bulk organic matter straddles a major lithologic change (Fig. 2). This was the first GSSP to use a stable isotopic event as a primary means of correlation. This innovative step resulted in: 1) the ability to correlate with very high (10's kyr) resolution since the entire CIE spanned $<200 \mathrm{kyr}$ of the earliest Eocene, including the main decrease, a subsequent period of low $\delta^{13} \mathrm{C}$ values spanning $\sim 40$ $80 \mathrm{kyr}$ (the "core" of Röhl et al., 2007), and an exponential recovery of $\sim 100 \mathrm{kyr}$ (Dickens et al., 1997; Röhl et al., 2007); 2) the CIE can be recognized in marine and non-marine carbonates and organic matter because the anomaly propagated through the atmosphere and can be measured in paleosols/teeth (Koch et al., 1992), though the $\delta^{13} \mathrm{C}$ decrease was higher $(\sim 6 \%)$ in terrestrial section due to a series of processes (Bowen et al., 2004); 3) it provided stability to nomenclature with the Paleocene-Eocene thermal maximum (PETM), with the event placed in the earliest Eocene. Though the maximum temperatures were in fact attained during the earliest Eocene $(\sim 60 \mathrm{~cm}$ above the initiation of the CIE at Southern Ocean Site 690; Thomas et al., 2002), the initiation of the sharp $\delta^{13} \mathrm{C}$ decrease is at the Paleocene/Eocene boundary.

Correlation of the Dababiya section with Southern Ocean Site 690 (Bains et al., 1999), marine sections from Millville and Wilson Lake, NJ (Wright and Schaller, 2013), and Polecat Bench, Wyoming terrestrial locality (Bowen et al., 2015; see also Magioncalda et al., 2004 for a similar comparison of Dababiya, Site 690, and Polecat Bench) illustrates the power of $\delta^{13} \mathrm{C}$ correlations (Fig. 2). The CIE initiation, "core", and recovery are recognizable from Egypt to the southern ocean to New Jersey. This comparison shows that "core" in the nearshore ( $\sim 60-80 \mathrm{~m}$ paleodepths) NJ sections are greatly expanded, with $10 \mathrm{~m}$ of the "core" versus $1.5 \mathrm{~m}$ at the other two sites. A similar comparison with the Polecat Bench, WY section shows that it is even more expanded (over $40 \mathrm{~m}$ for "core" $\delta^{13} \mathrm{C}$ values; Magioncalda et al., 2004; Bowen et al., 2015).

Placement of the base of the Eocene at the initiation of the CIE is gratifying in that most of the major Lyellian boundaries of the Cenozoic were thought to be at or near major shifts in climate, oceanography, or sea level (Berggren, 1971, 1972). Though boundaries should not be intrinsically tied to climate change, which can cause diachronous biotic response (e.g., Haq, 1980), it is useful when major stratigraphic boundaries are at major changes in Earth history, as is certainly the case for the $\mathrm{K} / \mathrm{Pg}$ and $\mathrm{P} / \mathrm{E}$ boundaries, and in such cases the GSSPs foster marine and terrestrial correlations (Fig. 2) and communication of geologists with the public. Such is not the case for the Eocene/Oligocene (E/O) boundary.

\section{The Eocene/Oligocene boundary and the Eocene Oligocene transition (EOT)}

The base of the Oligocene was originally placed at the base of the Rupelian Stage (Berggren, 1971, 2007). Scientific battles have been waged over the correlation of the Eocene/Oligocene (E/O) boundary, with foraminiferal specialists favoring the extinction of the tropicalsubtropical genus Hantkenina and nannofossil specialists favoring the extinction of rosette-shaped discoasters Discoaster barbadiensis and D. saipanensis that occurred $\sim 0.1 \mathrm{Myr}$ earlier (Snyder et al., 1984). The relationships between these extinction events and a large mammalian turnover in Europe (the Grande Coupure; Hooker et al., 2004), 


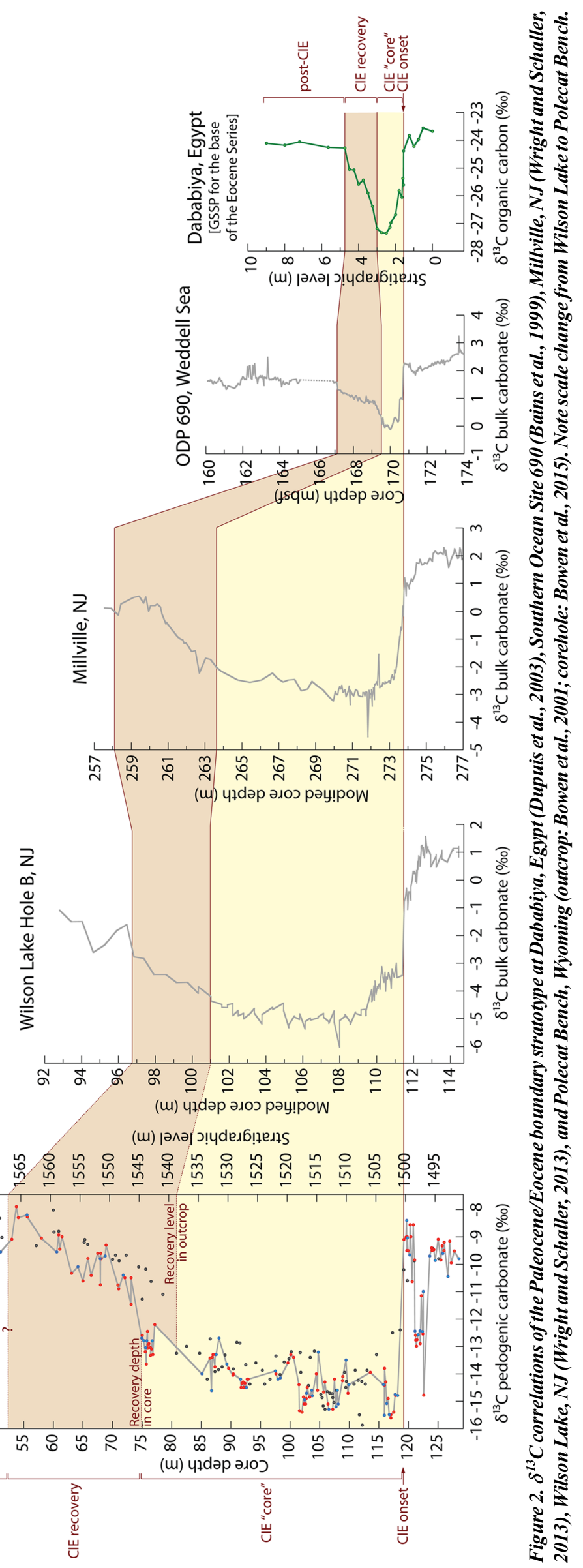




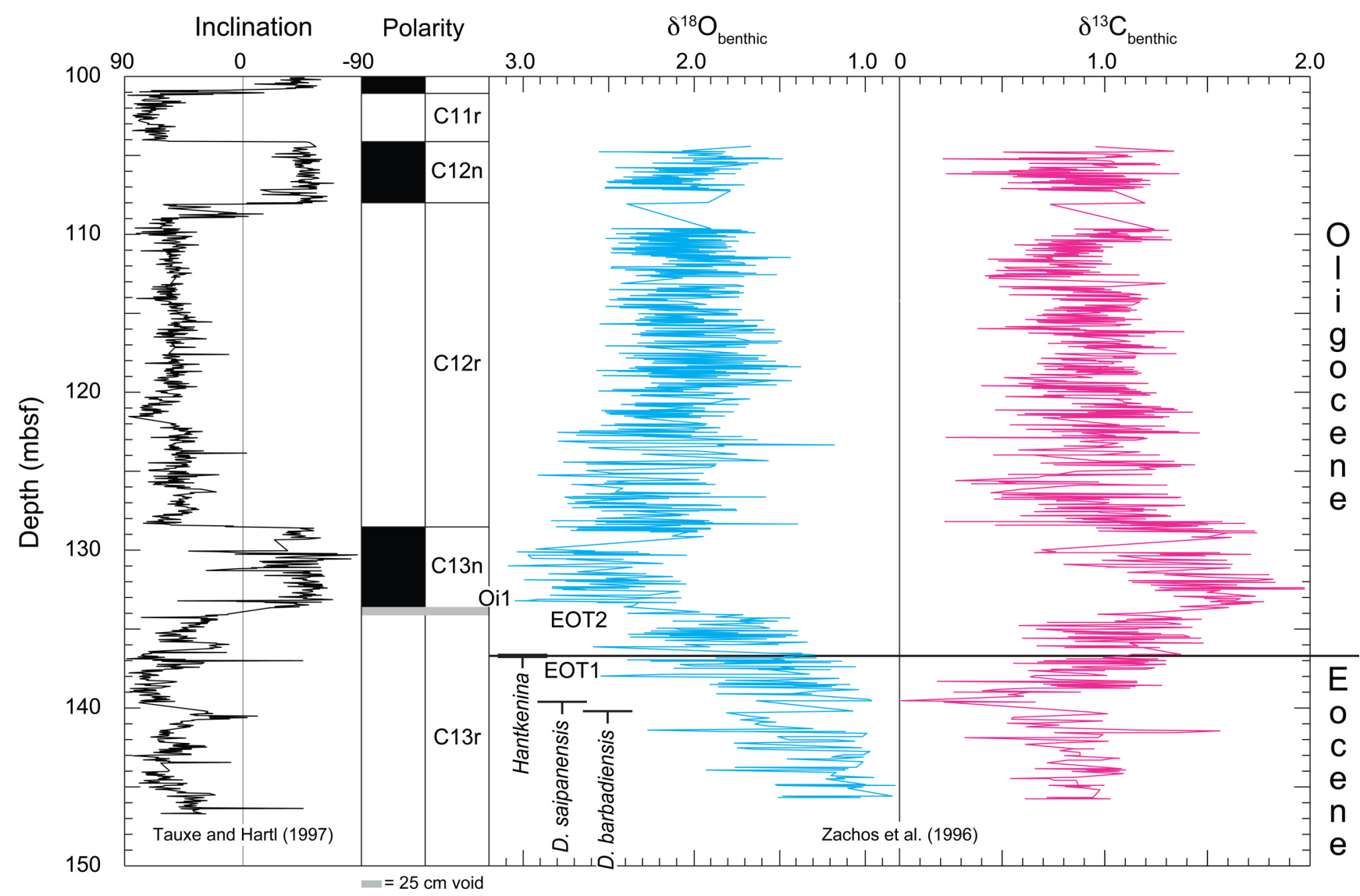

Figure 3. South Atlantic Site 522 inclination, polarity, and magnetochronozones from Tauxe and Hart (1977), biostratigraphy of Poore et al. (1982), and benthic foraminiferal stable isotopes from Zachos et al. (1996). The Eocene/Oligocene boundary is placed at the HO of Hantkenina spp. (Premoli Silva et al., 1988).

sea-level fall (Vail et al., 1977; Miller et al., 1985), and a major increase in deep-sea $\delta^{18} \mathrm{O}$ (Savin et al., 1975; Kennett and Shackleton, 1977) and $\delta^{13} \mathrm{C}$ values (Zachos et al., 1996) were also uncertain. A purported mass extinction event at or near the E/O boundary (Raup and Sepkoski, 1982) turned out to be an artifact of a slower, protracted turnover in marine organisms (e.g., Aubry and Bord, 2009), yet the Eocene-Oligocene transition (EOT) remains one of the most important oceanographic and sea-level events of the Cenozoic (e.g., Miller et al., 1991; Zachos et al., 1992, 2001; Katz et al., 2008; Cramer et al., 2009). However, the E/O and EOT are not the same, with the stepwise EOT beginning before the boundary and the major $\delta^{18} \mathrm{O}$ increase and attendant Oil $\delta^{18} \mathrm{O}$ maximum (Miller et al., 1991) postdating the boundary by over 0.1 Myr (Fig. 3; Katz et al., 2008; Pearson et al., 2015). The EOT included two precursor steps (EOT1 and EOT2) that bracket the Eocene/Oligocene boundary as correlated by Hantkenina (Katz et al., 2008; Wade and Pearson, 2008), though the main event $\left(\sim 1.0 \% 0 \delta^{18} \mathrm{O}\right.$ increase) was defined at the maximum $\delta^{18} \mathrm{O}$ values as Oil.

After careful deliberation, a boundary stratotype for the base of the Oligocene was designated at Massignano, Italy (Premoli Silva et al., 1988). The section has a magnetostratigraphy (though a reported second normal in Chronozone C13 by Bice and Montanari (1998) turned out to be spurious), and excellent biostratigraphic control, although the section is diagenetically altered for oxygen isotopes (Odin et al., 1988; Premoli Silva et al., 1988). The GSSP was set at placed at $19 \mathrm{~m}$ in the
Massignano section at the level of the highest occurrence of Hantkenina (Premoli Silva et al., 1988) above the extinction of the rosette shaped discoasters (15 $\mathrm{m}$ in the section), but below the Chronozone $\mathrm{C} 13 \mathrm{n} / 13 \mathrm{r}$ boundary (20.5 $\mathrm{m}$ in the section).

Though the establishment of a GSSP stabilized and led to advance in paleoceanography and sea-level studies of the EOT, in many ways, placement of the E/O GSSP is unfortunate. Hantkenina is restricted to tropical and subtropical environments and is readily reworked as demonstrated at St. Stephens Quarry, AL (SSQ; Miller et al., 2008). The Chron $\mathrm{C} 13 \mathrm{n} / 13 \mathrm{r}$ boundary is recognizable in marine (e.g., SSQ) and non-marine sections, facilitating interregional correlations, but not precise correlation of the boundary as currently defined. More importantly, the major deep-sea $\delta^{18} \mathrm{O}$ increase associated with Oil (Miller et al., 1991) has a first-order correlation with the Chronozone $\mathrm{C} 13 \mathrm{n} / 13 \mathrm{r}$ boundary at Site 522 (Fig. 3) and SSQ; maximum benthic foraminiferal $\delta^{18} \mathrm{O}$ values (= definition of Oil isotopic chron) occur in basal Chronozone C13n (Fig. 3; Tauxe and Hartl, 1997; Zachos et al., 1996). Oi1 is the largest $(>1 \%$ in deep sea benthic foraminifera) and amongst the most rapid $\delta^{18} \mathrm{O}$ increases of the Cenozoic (Miller et al., 1987, 1991; Zachos et al., 1996, 2001; Cramer et al., 2009) and it is associated with a large marine $\delta^{13} \mathrm{C}$ (Zachos et al., 1996) and a smaller nonmarine $\delta^{13} \mathrm{C}$ increase (Zanazzi et al., 2007) across the Chron C13n/ $\mathrm{C} 13 \mathrm{r}$ boundary and $\delta^{13} \mathrm{C}$ maximum in early $\mathrm{C} 13 \mathrm{r}$ that represents a global perturbation of the carbon cycle, giving potential for marine to 
non-marine correlations. The $\delta^{18} \mathrm{O}$ increase is causally related to development of a continental scale ice sheet in Antarctica for the first time since the Carboniferous and a major sea-level fall ( $\sim 60 \mathrm{~m}$; Miller et al., 2005, 2008). First-order correlations of $\delta^{18} \mathrm{O}$, the $\mathrm{C} 13 \mathrm{n} / 13 \mathrm{r}$ boundary, and proxies for a sea level fall at SSQ testify to the strength of this correlation (Miller et al., 2008). In contrast, placement of the E/O using the GSSP is not possible at SSQ due to reworking. The major mammalian turnover in Europe (the Grande Coupure) is correlated with Chron C13n, though its exact placement is not certain due to a hiatus (Hooker et al., 2004).

We suggest that it is desirable to relocate the E/O GSSP to level $20.5 \mathrm{~m}$ at Massignano that records the Chron $\mathrm{C} 13 \mathrm{n} / \mathrm{C} 13 \mathrm{r}$ boundary and elsewhere the $\delta^{18} \mathrm{O}$ and $\delta^{13} \mathrm{C}$ increases (see also Brinkhuis and Visscher, 1995). Not only is this magnetochron readily correlatable amongst marine and non-marine sections (Zanazzi et al., 2007), it is also associated with the Oil $\delta^{18} \mathrm{O}$ increase and attendant $\delta^{13} \mathrm{C}$ increase. This is a major climatic, oceanographic, and sea-level event that marks the beginning of the modern icehouse (Miller et al., 1991; Zachos et al., 2001). Though a GSSP should be placed first on clear lithologic levels associated with criteria for correlations (in this case paleomagnetics, oxygen and carbon isotopes), it is useful to have them associated with major events in Earth history. The extinction of Hantkenina, is not such an event, even though it though recognizable, clear, bracketed by two isotopic events, and associated with radiolarian and large foraminiferal extinctions (Pearson et al., 2015). Oil and the Chron C13n/ $\mathrm{C} 13 \mathrm{r}$ boundary are such events, both with potential for marine-terrestrial correlations (Zanazzi et al., 2007).

The lack of unaltered $\delta^{18} \mathrm{O}$ records in the GSSP section at Massignano suggests a lectostratotype should be designated that includes first-order correlations of $\delta^{18} \mathrm{O}, \delta^{13} \mathrm{C}$, Sr-isotope, magneto-, and biostratigraphy. In this case we propose that Site 522 serve as a lectostratotype for isotopic reference section with its excellent magnetostratigraphy (Poore et al., 1982; Tauxe and Hartl, 1997), orbital-scale stable isotope stratigraphy (Zachos et al., 1996), Sr-isotopes stratigraphy (DePaolo and Ingram, 1985; Miller et al., 1988; Reilly et al., 2002), and planktonic foraminiferal and nannofossil biostratigraphy (Poore et al., 1982) (Fig. 3). It is intriguing that $\delta^{13} \mathrm{C}$ records in the boundary stratotype, albeit with limited data, show at distinct increase of $0.5 \%$ with high $\delta^{13} \mathrm{C}$ values persisting through Chron 13n (Odin et al., 1988), as seen at Site 522.

\section{The Oligocene/Miocene boundary}

After a long search due to a paucity of good candidates, the Oligocene/Miocene boundary was placed $35 \mathrm{~m}$ down from the top of the Lemme-Carrosio section in northwestern Italy at a distinct lithologic boundary between a massive limestone and overlying stratified limestone (Steininger et al., 1997). The section has an uncertain magnetostratigraphy, with only 2 of the three normal polarity intervals of C6C possibly represented; level 35 was thought to be the base of concatenated Chronozone C6Cn.2n/3n (Steininger et al., 1997), though a recent study suggests that the base of $\mathrm{C} 6 \mathrm{C} 2 \mathrm{n}$ cannot be determined (Aubry, 2015). Biostratigraphic criteria bracket the GSSP, with the closest including the highest occurrence (HO) of Sphenolithus delphix $4 \mathrm{~m}$ above the GSSP and the lowest occurrence (LO) of Paragloborotalia kugleri 2 meters above the boundary. Stable isotopes were run on bulk carbonate at Lemme-Carrosio (Corfield and Cartlidge, 1996), but covariance of percent carbonate and $\delta^{18} \mathrm{O}$ especially from 38-60 m indicate diagenetic overprint. Nevertheless, Corfield and Cartlidge (1996) and Steininger et al. (1997) suggested that a $\delta^{18} \mathrm{O}$ increase from the base of the section (level $60 \mathrm{~m}$ ) to $\sim 15 \mathrm{~m}$ might represent the global $\delta^{18} \mathrm{O}$ increase and attendant Mi1 $\delta^{18} \mathrm{O}$ maximum of Miller et al. (1991). A primary stable isotopic record based on foraminifera is needed to resolve this issue. At this point, it is unwise to apply a correlative scheme based on a likely altered bulk isotope record.

Problems with the Lemme-Carrosio section and with deep-sea sections have hampered correlations despite the fact that the boundary is generally associated with the Mil $\delta^{18} \mathrm{O}$ increase (Miller et al., 1991), an attendant $\delta^{13} \mathrm{C}$ increase (Zachos et al., 2001), and a major sea-level fall (Miller et al., 2005). Site 522 was designated as the reference section for the Mi1 increase (Miller et al., 1991), with the increase beginning in $\mathrm{C} 6 \mathrm{Cn} 3$ and reaching maximum values (= definition of Mi1) in a thin reversed interval identified as $\mathrm{C} 6 \mathrm{C} 2 \mathrm{r}$. In their recalibration of the Oligocene/Miocene boundary to an astronomical age of 22.9 Ma, Shackleton et al. (2000) correlated magnetic susceptibility cycles in Ceara Rise Sites 925, 926, 928, and 929 to the magnetostratigraphy at Site 522 using bulk $\delta^{13} \mathrm{C}$ and the short ranging nannofossil Sphenolithus delphix. They reinterpreted the magnetostratigraphy at Site 522 of Tauxe and Hartl (1977) and concluded that Oligocene/Miocene boundary as placed at Lemme-Carrosio at $35 \mathrm{~m}$ was close to $\mathrm{C} 6 \mathrm{Cn} .2 \mathrm{n}$, but that the paleomagnetic assignment was not certain.

Stable isotopic and magnetostratigraphy correlations at Southern Ocean Site 1090 provide clarity to correlations (Fig. 4). The magnetostratigraphy spanning the Oligocene/Miocene boundary at this site is exceptional, comprising a square wave with resolution of all three normal subchrons of $\mathrm{C} 6 \mathrm{Cn}$ in an interval over $10 \mathrm{~m}$ thick (Fig. 4; Channell et al., 2003). Benthic foraminiferal $\delta^{18} \mathrm{O}$ records allow clear identification of the increase and Mi1 maximum in upper $\mathrm{C} 6 \mathrm{C} 2 . r 2$ (Fig. 4; Billups et al., 2002). An attendant benthic foraminiferal $\delta^{13} \mathrm{C}$ increase and maximum are associated with the $\delta^{18} \mathrm{O}$ increase and Mi1 maximum (Fig. 4). Shackleton et al. (2000) showed that a bulk carbonate $\delta^{13} \mathrm{C}$ increase at Site 522 is associated with an increase in abundance and acme of S. delphix in C6C2.r2. They also showed this acme at $38 \mathrm{~m}$ in the Lemme-Carrosio section, $3 \mathrm{~m}$ below the GSSP. This leaves open the unequivocal correlation of the Oligocene/Miocene boundary, because the magnetostratigraphy of the Lemme-Carrosio section is equivocal, the $\delta^{18} \mathrm{O}$ and $\delta^{13} \mathrm{C}$ increases and maxima predate the boundary as currently defined, and there are no biohorizons to precisely correlate the boundary.

A solution to this problem would be to designate Site 1090 as a lectostratotype for the Oligocene/Miocene boundary for isotopic and magnetostratigraphic correlations. The Mi1 increase and maximum can be used for marine correlations, along with the LO of P. kugleri, and the maximum of $S$. delphix as calibrated at Site 522. The carbon isotopic increase and maximum can be used for marine-terrestrial correlation. Unfortunately, the high latitude of the site $\left(43^{\circ} \mathrm{S}\right)$ precludes application of standard planktonic foraminiferal and nannofossil zonations, though the LO of Globigerinoides spp. is noted in lower Chron C6Cn.r1 (Galeotti et al., 2002; Marino-and Flores, 2002). The absence of biostratigraphic markers precludes designation of Site 1090 as the holostratotype replacing the Lemme-Carrosio section. Also, correlation to the current holostratotype in uncertain and $\sim 1 \mathrm{~m}$ offset between the peak values of Mil and the base of Chronozone C6Cn.2n base at Site 


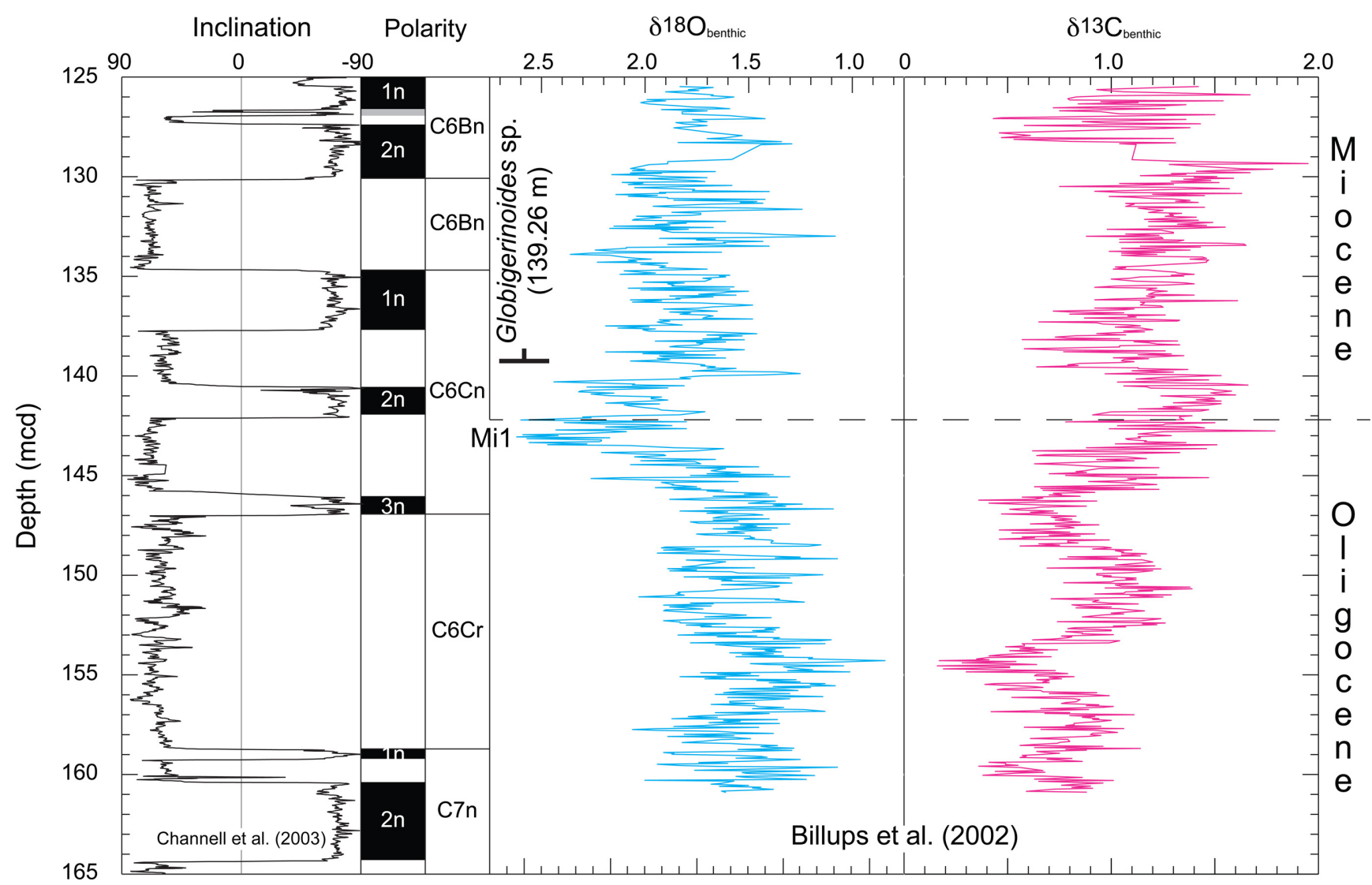

Figure 4. Southern Ocean Site 1090 inclination, polarity, and magnetochronozones from Channell et al. (2003), the LO of Globergerinoides spp. (Galeotti et al., 2002), and benthic foraminiferal stable isotopes from Billups et al. (2002). The Oligocene/Miocene boundary is dashed at the base of C6C.2n based on suggested correlations of Steininger et al. (1997) from the Lemme-Carrosio section.

1090 represents about $50 \mathrm{kyr}$ (using sedimentation rates of $\sim 2 \mathrm{~cm} / \mathrm{kyr}$; Billups et al., 2002).

Other deep-sea sections mimic the stable isotopic record at Site 1090, including Sites 926, 929, and 1334. In particular, equatorial Pacific Site 1334 (Beddow et al., 2016) shows the same first-order correlation of magnetostratigraphy (Channell et al., 2013) and stable isotopes as Site 1090. Site 1334 should be considered as a possible replacement of Lemme-Carrosio section as the holostratotype and GSSP because of its biostratigraphic control, which is limited at Site 1090.

We do not illustrate the Miocene/Pliocene boundary here because neither magnetostratigraphy nor isotopic stratigraphy is useful for precise correlation of the boundary. The GSSP was placed at the base of the Zanclean Stage at Eraclea Minoa, Italy, at a lithologic break from Lago to marine marking the deluge (Castradori, 1998). There is little stable isotopic signature of this event (Hodell et al., 2001), though the GSSP is 5 precessional sapropel-marl cycles (\#510) down from base of the Thvera Subchron, which provides potential for global correlation.

\section{The Pliocene/Pleistocene boundary and the "initi- ation of northern hemisphere glaciation"}

The Pliocene/Pleistocene boundary has a long and controversial history (e.g., Berggren, 1971; Berggren and Van Couvering, 1974; Gibbard et al., 2010) that is briefly reviewed here. The Gelasian Stage was named for the upper part of the Pliocene, with the GSSP placed at level $62 \mathrm{~m}$ at the base of a marl overlying astronomically correlated sapropel 250 in the Monte San Nicola section near the town of Gela, Sicily (Rio et al., 1998). This sapropel lies $27 \mathrm{~m}$ above the contact of the Trubi and the Monte Narbone Formations and is correlated with Marine Isotope Chron (MIC) 103 with an astronomical age of $2.58 \mathrm{Ma}$ (Lisiecki and Raymo, 2005) based on cyclostratigraphy on the abundances of Globigerinoides ruber (Rio et al., 1998). With the approval of the Executive Committee of the International Union of Geological Sciences (IUGS), the base of the Quaternary (encompassing the Pleistocene and Holocene) was lowered to the base of Gelasian, decapitating the Upper Pliocene (Gibbard et al., 2010). The Neogene Period was similarly decapitated and restricted to the Miocene and Pliocene Epochs, with the Neogene/ Quaternary and Pliocene/Pleistocene boundaries placed in the Monte San Nicola section GSSP.

It is useful to view this Pliocene/Pleistocene boundary in the context of $\delta^{18} \mathrm{O}$ stratigraphy, the backbone of Pleistocene correlations (Shackleton and Opdyke 1973; Berggren et al., 1995b). The Lisiecki and Raymo (2005) $\delta^{18} \mathrm{O}$ stack (Fig. 5) provides an excellent reference for Marine Isotope Chrons (MIC; although called Marine Isotope Stages in the literature, the term stage should be restricted to the time-rock equivalent of age, especially considering that the time significance and duration of $\delta^{18} \mathrm{O}$ events warrants the use of the term "chron"). The Lisiecki-Raymo stack illustrates the major MIC versus the astronomically calibrated Geomagnetic Polarity Time Scale (GPTS; Fig. 5). 


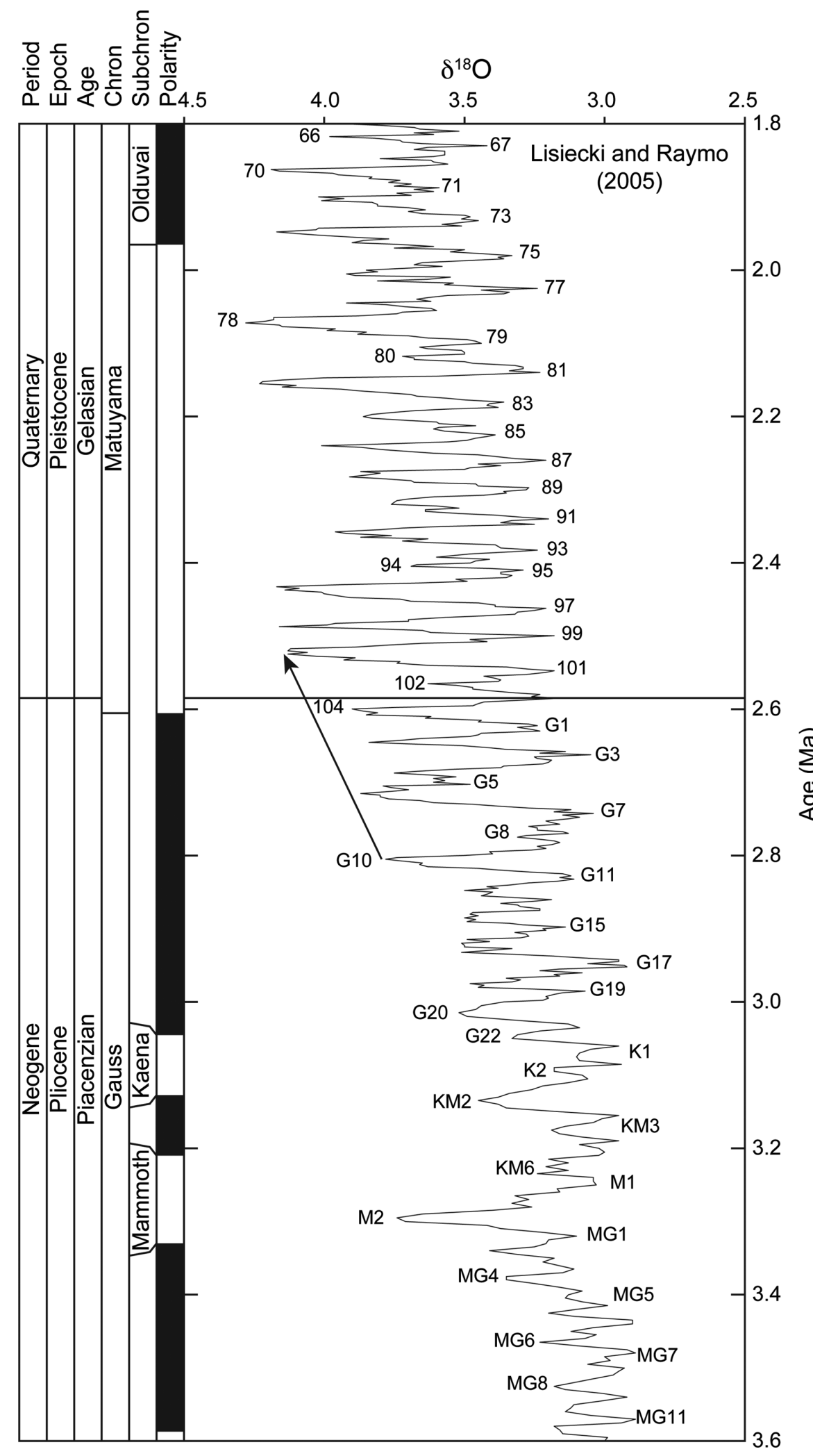

Figure 5. Geomagnetic Polarity Time scale and $\delta^{18}$ O chrons replotted after Lisiecki and Raymo (2005). Arrow indicates interval from Chron $G 10$ to 100 of progressively larger $\delta^{18} O$ increases associated with development of the Laurentide ice ages. GSSP is at the base of the Gelasian Stage correlated to Marine Isotope Chron 103 (Rio et al., 1998).

One of the reasons that the base of the Pleistocene was redefined from its previous GSSP at Vrica, Italy (astronomical age based on sapropelmarl cycles of $1.88 \mathrm{Ma}$ ) is that the GSSP "should be located earlier in the geological record at a time of much greater change in the Earth system" (Gibbard et al., 2010; p. 99). Researchers working on Pliocene-Pleistocene have advocated for the restoration of the Quaternary to system/period scale (this was ratified by the ICS in 2007; Gibbard et al., 2010) and have long viewed climate and evolutionary changes from 2.5-2.6 Ma as seminal ("cooling" of Gibbard et al., 2010). This "cooling" is partly based on (Fig. 5) marine $\delta^{18} \mathrm{O}$ increase changes that reflect $\sim 2 /$ 3 ice volume and $1 / 3$ temperature changes (e.g., Fairbanks, 1989).

A large $(>1 \%) \delta^{18} \mathrm{O}$ increase assigned to MIC 100 was first well-dated near the Matuyama/ Gauss boundary at Site 552 on Rockall Plateau and first-order correlated with the apparent first appearance of dominant IRD in the northern North Atlantic (Shackleton et al., 1984). Dubbed "the initiation of Northern hemisphere glaciation," the event should be termed the beginning of the northern hemisphere ice ages or the initiation of the Laurentide ice sheet: 1) IRD occurs in the in the Eocene in the Arctic ส (St. John, 2008) and Greenland Basin (Eldrett $\sum$ et al., 2007), again in the Middle Miocene in of the Norwegian-Greenland Sea (Wolf-Welling et al., 1996), and at Site 552 prior to MIC 100 in MIC 102, where MIC 103-104 are not represented due to a coring gap (Curry and Miller, 1989); 2) Upper Miocene (ca. 7 Ma) grounded tills were cored off East Greenland (Larsen et al., 1994), clearly establishing the presence of an ice sheet at least in Greenland; prior to the "initiation"; 3) the interval from isotope chron G 10 (ca. $2.8 \mathrm{Ma}$ ) to MIC 100 represents a progressive increase in $\delta^{18} \mathrm{O}$ glacial-interglacial amplitudes, suggesting that the increase in the amplitude of ice-volume increases was a progressive process rather than an event, as previously noted by Gibbard et al. (2010); and 4) from MIC 100 on, $\delta^{18} \mathrm{O}$ amplitudes were large (Fig. 5), reflecting an increase in the amplitude of ice-volume increases (Shackleton and Opdyke, 1972; Shackleton et al., 1984 Lisiecki and Raymo, 2005). These large amplitude changes can only be explained by growth and decay of significant Laurentide ice sheets with accompanied cooling and warming, though glaciation (albeit minor, Greenland scale) was already underway in the northern hemisphere over $40 \mathrm{Myr}$ prior to this.

From an isotopic and paleomagnetic perspective, placement of the GSSP at MIC 103 is unfortunate since it is a minor $\delta^{18} \mathrm{O}$ fluctuation, a poor marker for correlation, and post-dates the Matuyama/Gauss boundary by $\sim 20$ kyr. Though MIC 103 is well 
tied to the Mediterranean sapropel chronology, it is not as easily correlated out of this region as the Matuyama/Gauss boundary or even MIC 100. The base Gelasian could be redefined to improve precise correlations: 1) the ideal location would be at the Matuyama/Gauss boundary which is associated with MIC 104; this would involve moving the GSSP down $\sim 1.5 \mathrm{~m}$ (Rio et al., 1998); or 2) at MIC 100 as the most prominent $\delta^{18} \mathrm{O}$ chron, some $80 \mathrm{kyr}$ after the Matuyama/Gauss boundary and $\sim 3 \mathrm{~m}$ upsection in the Monte San Nicola based on abundance of G. ruber (Rio et al., 1998). We favor moving the GSSP to a level equivalent to MIC 104 because this allows the correlations of marine and terrestrial sections using magnetostratigraphy. Note that none of these placements, including the current one, provide a precise means of correlating marine sections with the GSSP using either nannofossils (Rio et al., 1998) or planktonic foraminifera (Wade et al., 2011) because their LO and HO bracket this interval.

\section{Conclusions}

We provide 2 examples where placement of golden spikes in association with reversals and global geochemical events has been successful:

1) The Cretaceous/Paleogene $(\mathrm{K} / \mathrm{Pg})$ boundary is placed at a level with an Iridium spike that provides a global correlation tool, albeit sometimes complicated by mobility of Ir due bioturbation and re-concentration at redox boundaries.

2) The Paleocene/Eocene boundary was placed at the initiation of the Carbon Isotopic Excursion, and the $\delta^{13} \mathrm{C}$ decrease is particularly useful in marine-terrestrial correlations.

We discuss three boundaries where placement of the GSSP is unfortunately not at distinct isotopic or magnetostratigraphic events.

1) The golden spike at the base of Oligocene was placed at a level containing the highest occurrence of the planktonic foraminifera Hantkenina, resulting not only in problems in correlation to terrestrial and marginal marine strata, but the unfortunate placement of the largest Cenozoic $\delta^{18} \mathrm{O}$ increase as the "earliest Oligocene glaciation." The boundary stratotype could be (re)placed at a level recording the base of Chronozone $\mathrm{C} 13 \mathrm{n}$ in association with the $\delta^{18} \mathrm{O}$ increase associated with a global sea-level fall, growth of a continental scale ice sheet, and a large $\delta^{13} \mathrm{C}$ increase that would facilitate in marine to terrestrial correlations.

2) There are problems with the GSSP for Oligocene/Miocene boundary which was placed at a level thought to be the base of Chronozone $\mathrm{C} 6 \mathrm{Cn} 2 \mathrm{n}$ and correlated with Mi1 $\delta^{18} \mathrm{O}$ maximum; however, first-order magnetostratigraphic and isotopic correlations at Sites 1090 and 522 show that the Mi1 $\delta^{18} \mathrm{O}$ increase and maximum and attendant $\delta^{13} \mathrm{C}$ increase and maxima occur in upper Chronzone C6Cn.2r.

3) The Pliocene/Pleistocene (= Neogene/Quaternary) boundary is placed at a relatively minor interglacial (MIC 103) some $20 \mathrm{kyr}$ after the Matuyama/Gauss boundary and $60 \mathrm{kyr}$ before the large amplitude MIC 100. Though incorrectly dubbed "the initiation of northern hemisphere glaciation", MIC 100 represents the first major Laurentide ice sheets and should be termed "the initiation of northern hemisphere ice ages."

We conclude that use of biostratigraphic markers as the primary correlation tool for placement of GSSP is less desirable than use of magnetostratigraphic or chemostratigraphic markers because biostra- tigraphic markers are not globally correlatable. Biostratigraphy remains essential for placing magnetostratigraphy and isotopic stratigraphy into a correct time frame, but lacks the temporal precision and global dimension of magnetostratigraphy and stable isotopic stratigraphy. We note that a new holostratotype section should be identified for the $\mathrm{K} / \mathrm{Pg}$ boundary that has a politically inaccessible GSSP (as might the $\mathrm{P} / \mathrm{E}$ boundary) and suggest that placement of new GSSPs for the E/O (e.g., moving it $1.5 \mathrm{~m}$ up in the Massignano section designating an isotopic lectostratotype at Site 522), O/M (designating an isotopic lectostratotype at Site 1090 and considering moving the GSSP to Site 1334), and N/Q (moving it to the equivalent of MIC 104 and the Matuyama/ Gauss boundary) boundaries be discussed.

\section{Acknowledgements}

The views expressed here developed with discussions of stratotypes and biostratigraphy with M.-P. Aubry, magnetostratigraphy and GSSPs with D.V. Kent, and biostratigraphy with W.A. Berggren. W. Piller encouraged the paper and I. Raffi provided discussion of Neogene GSSPs. K/Pg boundary studies benefited from discussions with S. Esmeray-Senlet, R.K. Olsson, and J.V. Browning. PETM studies benefited from discussions with M.P. Aubry and M. Makarova. Eocene/ Oligocene boundary studies benefited from discussions with M. Katz, P. Pearson, and B. Wade. The paper benefited from comments from D.V. Kent, M.-P. Aubry, and an anonymous reviewer. J.V. Browning and M. Makarova drafted the figures. Supported by NSF grant OCE1463759 (KM).

\section{References}

Alegret, L., and Thomas, E., 2009, Food supply to the seafloor in the Pacific Ocean after the Cretaceous/Paleogene boundary event: Marine Micropaleontology, v.73, nos.1-2, pp. 105-116. doi:10.1016/j.marmicro. 2009.07.005.

Alegret, L., Thomas, E., and Lohmann, K.C., 2012, End-Cretaceous marine mass extinction not caused by productivity collapse: Proceedings of the National Academy of Sciences, v.109, no.3, pp. 728-732. doi:10.1073/pnas.1110601109/-/DCSupplemental/ST01.doc

Alvarez, W., Arthur, M.A., Fischer, A.G., Lowrie, W., Napoleone, G., Silva, I.P., and Roggenthen, W.M., 1977, Upper Cretaceous-Paleocene magnetic stratigraphy at Gubbio, Italy V. Type section for the Late Cretaceous-Paleocene geomagnetic reversal time scale: Geological Society of America Bulletin, v.88, no.3, pp. 383-389.

Alvarez, L.W., Alvarez, W., Asaro, F., and Michel, H.V., 1980, Extraterrestrial cause for the Cretaceous-Tertiary extinction: Science, v.208, no.4448, pp. 1095-1107. doi: 10.1126/science.208.4448.1095

Arens, N.C., and Jahren, A.H., 2000, Carbon isotope excursion in atmospheric $\mathrm{CO}_{2}$ at the Cretaceous-Tertiary Boundary: Evidence from terrestrial sediments: Palaios, v.15, no.4, pp. 314-322.

Arenillas, I., Arz, J.A., Molina, E., and Dupuis, C., 2000, An independent test of planktic foraminiferal turnover across the Cretaceous/Paleogene $(\mathrm{K} / \mathrm{P})$ boundary at El Kef, Tunisia: Catastrophic mass extinction and possible survivorship: Micropaleontology, v.46, no.1, pp. 31-49.

Aubry, M.-P., 1995, From chronology to stratigraphy: Interpreting the stratigraphic record, in Berggren, W.A., Kent, D.V., Aubry, M.-P., and Hardenbol, J., eds., Geochronology, Time scales and Global Stratigraphic Correlations: A Unified Temporal Framework for an Historical Geology. Society of Economic Geologists and Mineralogists Special Vol- 
ume 54, pp. 213-274.

Aubry, M-P., 1988, France, The Paris Basin, in Vinker, R., ed., The Northwest European Tertiary Basin, Results of the International Geological Correlation Programme, Project no 124: Geologisches Jahrbuch, reihe A, heft 100, pp. 264-266.

Aubry, M.-P., 2007, Chronostratigraphy beyond the GSSP: Stratigraphy, v.4, pp. 27-137.

Aubry, M.P., and Berggren, W.A., 2015, Cenozoic bio- and chronostratigraphy: state of the art, $52^{\text {nd }}$ International Congress on Stratigraphy STRATI 2015, 19-23 July, Graz, Austria, pp. 18.

Aubry, M.P., and Bord, D., 2009, Reshuffling the cards in the photic zone at the Eocene/Oligocene boundary: Geological Society of America Special Paper, v.452, pp. 279-301.

Aubry, M.P., Ouda, K., Dupuis, C., Berggren, W.A., Van Couvering, J.A., Ali, J., Brinkhuis, H., Gingerich, P.R., Heilmann-Clausen, C., Hooker, J., and Kent, D.V., 2007, The global standard stratotype-section and Point (GSSP) for the base of the Eocene Series in the Dababiya section (Egypt): Episodes, v.30, no.4, pp. 271-286.

Bains, S., Corfield, R.M., and Norris, R.D., 1999, Mechanisms of climate warming at the end of the Paleocene: Science, v.285, no.5428, pp. 724727

Beddow, H.M., Liebrand, D., Sluijs, A., Wade, B.S., and Lourens, L.J., 2016, Global change across the Oligocene-Miocene transition: Highresolution stable isotope records from IODP Site U1334 (equatorial Pacific Ocean): Paleoceanography, v.31, no.1, pp. 81-97. doi:10.1002/ 2015PA002820.

Berggren, W.A, 1971, Tertiary boundaries and correlations, in Funnell, R.M.S., and Riedel W.R., eds., The micropaleontology of oceans: Cambridge University Press, pp. 693-809.

Berggren, W.A., 1972, A Cenozoic time-scale - some implications for regional geology and paleobiogeography: Lethaia, v.5, no.2, pp. 195215.

Berggren, W.A., 2007, Status of the hierarchical subdivision of higher order marine Cenozoic chronostratigraphic units: Stratigraphy, v.4, no.2-3, pp. 99-108.

Berggren, W.A., and Aubry, M.-P.,1998, The Paleocene/Eocene Epoch/ Series boundary: Chronostratigraphic framework and estimated geochronology, in Aubry, M.-P., Lucas, S., and Berggren, W.A., eds., Late Paleocene-Early Eocene Climatic and Biotic Events in the Marine and Terrestrial Records, Columbia University Press, pp. 18-36.

Berggren, W.A., and Van Couvering, J.A., 1974, The late Neogene: Palaeogeography, Palaeoclimatology, Palaeoecology, v.16, pp. 1-215.

Berggren, W.A., Hilgen, F.J., Langereis, C.G., Kent, D.V., Obradovich, J.D., Raffi, I., Raymo, M.E., and Shackleton, N.J., 1995b, Late Neogene chronology: new perspectives in high-resolution stratigraphy: Geological Society of America Bulletin, v.107, no.11, pp. 1272-1287.

Berggren, W.A., Kent, D.V., Swisher, C.C., and Aubry, M.-P., 1995a, A revised Cenozoic geochronology and chronostratigraphy, in Berggren, W.A., Kent, D.V., and Hardenbol, J., eds., Geochronology, Time Scales And Global Stratigraphic Correlations: A Unified Temporal Framework For An Historical Geology: SEPM (Society for Sedimentary Geology) Special Publication 54, pp. 129-212.

Billups, K., Channell, J.E.T., and Zachos, J.C., 2002, Late Miocene through early Pliocene deep water circulation and climate change viewed from the sub-Antarctic South Atlantic: Palaeogeography, Palaeoclimatology, Palaeoecology, v.185, no.3, pp. 287-307.

Bowen, G.J., Koch, P.L., Gingerich, P.D., Norris, R.D., Bains, S., and Corfield, R.M., 2001, Refined isotope stratigraphy across the continental Paleocene-Eocene boundary on Polecat Bench in the northern Bighorn Basin, in Gingerich, P.D., ed., Paleocene-Eocene Stratigraphy and Biotic Change in the Bighorn and Clarks Fork Basins, Wyoming, University Michigan Papers on Paleontology, v.33, pp. 73-88.

Bowen, G.J., Beerling, D.J., Koch, P.L., Zachos, J.C., and Quattlebaum, T., 2004, A humid climate state during the Palaeocene/Eocene thermal maximum: Nature, v.432, no.7016, pp. 495-499.
Bowen, G.J., Maibauer, B.J., Kraus, M.J., Röhl, U., Westerhold, T., Steimke, A., Gingerich, P.D., Wing, S.L., and Clyde, W.C., 2015, Two massive, rapid releases of carbon during the onset of the PalaeoceneEocene thermal maximum: Nature Geoscience, v.8., no.1, pp. 44-47.

Brinkhuis, H., and Visscher, H., 1995, The upper boundary of the Eocene series: a reappraisal based on dinoflagellate cyst biostratigraphy and sequence stratigraphy: SEPM Special Publication 54, pp. 295-304.

Castradori, D., 1998, Calcareous nannofossils in the basal Zanclean of Eastern Mediterranean: Remarks on paleoceanography and sapropel formation: Proceedings of the Ocean Drilling Program, Scientific Results, v.160, pp. 113-123.

Castradori, D., Rio, D., Hilgen, F.J., and Lourens, L.J., 1998, The Global Standard Stratotype-section and Point (GSSP) of the Piacenzian Stage (Middle Pliocene): Episodes, v.21, pp. 88-93.

Claeys, P., Kiessling, W., and Alvarez, W., 2002, Distribution of Chicxulub ejecta at the Cretaceous-Tertiary boundary: Geological Society of America Special Paper, v.356, pp. 55-68.

Channell, J.E.T., Ohneiser, C., Yamamoto, Y., and Kesler, M.S., 2013, Oligocene-Miocene magnetic stratigraphy carried by biogenic magnetite at sites U1334 and U1335 (equatorial Pacific Ocean): Geochemistry, Geophysics, Geosystems, v.14, no.2, pp. 265-282.

Colodner, D.C., Boyle, E.A., Edmond, J.M., and Thomson, J., 1992, Postdepositional mobility of platinum, iridium and rhenium in marine sediments: Nature, v.358, no.6385, pp. 402-404. doi: 10.1038/358402a0

Corfield, R.M., and Cartlidge, J.E., 1996, The stable isotope stratigraphy of the Global Stratotype Section and Point of the base of the Neogene (the Paleogene/Neogene boundary) at Lemme, Italy. A Data Report: Giornale di Geologia, ser. 3", vol.58, nos.1-2, pp. 105-110.

Cowie J.W., Zieger W., and Remane, J., 1989, Stratigraphic commission accelerates progress, 1984-1989: Episodes, v.112, no.2, pp. 79-83.

Cramer, B.S., Toggweiler, J.R., Wright, J.D., Katz, M.E., and Miller, K.G., 2009, Ocean overturning since the Late Cretaceous: Inferences from a new benthic foraminiferal isotope compilation: Paleoceanography, v.24, no.4, PA4216. http://dx.doi.org/10.1029/2008PA001683.

Curry, W.B., and Miller, K.G., 1989, Oxygen and carbon isotopic variation in Pliocene benthic foraminifers of the equatorial Atlantic, in Ruddiman, W., Sarnthein, M. et al., eds., Proceedings of the Ocean Drilling Program, Scientific results, Volume 108: College Station, Texas, Ocean Drilling Program, pp. 157-166.

DePaolo, D.J., and Ingram, B.L., 1985, High-resolution stratigraphy with strontium isotopes: Science, v.227, no.4689, pp. 938-940.

Dickens, G.R., Castillo, M.M., and Walker, J.C.G., 1997, A blast of gas in the latest Paleocene: Simulating first-order effects of massive dissociation of oceanic methane hydrate: Geology, v.25, no.3, pp. 259-262.

Dupuis, C., Aubry, M.-P., Steurbaut, E., Berggren, W.A., Ouda, K., Magioncalda, R., Cramer, B.S., Kent, D.V., Speijer, R.P., and Heilmann-Clausen, C., 2003, The Dababiya quarry section: Lithostratigraphy, clay mineralogy, geochemistry and paleontology: Micropaleontology, v.49, suppl. 1, pp. 41-59.

Eldrett, J.S., Harding, I.C., Wilson, P.A., Butler, E., and Roberts, A.P., 2007, Continental ice in Greenland during the Eocene and Oligocene: Nature, v.446, no.7132, pp. 176-179.

Esmeray-Senlet, S., Wright, J.D., Olsson, R.K., Miller, K.G., and Browning, J.V., 2015, Evidence of the living ocean following the Cretaceous/ Paleogene mass extinction: Paleoceanography, v.30, no.6, pp. 718 738. doi:10.1002/2014PA002724

Esmeray-Senlet, S., Miller, K.G., Sherrell, R.M., Senlet, T., Vellekoop, J., and Brinkhuis, H., 2017, Iridium profiles and delivery across the Cretaceous/Paleogene boundary: Earth and Planetary Science Letters, v.457, pp. 117-126.

Hedberg, H.D. (ed.), 1976, International stratigraphic guide: A guide to stratigraphic classification, terminology and procedure; International Subcommission on Stratigraphic Classification of IUGS Commission on Stratigraphy: New York, John Wiley and Sons, 200 pp.

Ebel, D.S., Mahmood, S., Jaret, S.J., Bigolski, J.N., Aldoroty, R.J., Sessa, 
J.A., and Landman, N.H., 2015, New Jersey, a most habitable place during an asteroid strike: Shocked quartz and iridium spike co-occur below a Maastrichtian mollusk community on the NJ coastal plain: Geological Society of America Abstracts with Programs, v.47, no.7, pp. 281

Fairbanks, R.G., 1989, A 17,000-year glacio-eustatic sea level record: Influence of glacial melting rates on the Younger Dryas event and deep-ocean circulation: Nature, v.339, p. 637-642.

Galeotti, S., Coccioni, R., and Gersonde, R., 2002, Middle Eocene-Early Pliocene subantarctic planktic foraminiferal biostratigraphy of Site 1090, Agulhas Ridge: Marine Micropaleontology, v.45, no.3, pp. 357381

Gibbard, P.L., Head, M.J., Walker, M.J.C., and The Subcommission onQuaternary Stratigraphy, 2010, Formal ratification of the Quaternary System/Period and the Pleistocene Series/Epoch with a base at 2.58 Ma: Journal of Quaternary Science, v.25, no.2, pp. 96-102.

Gradstein, F.M., Ogg, J.G., Schmidtz, M.D., and Ogg, G.M. (eds.), 2012, The geologic time scale: Elsevier, New York, 1144 pp.

Haq, B.U., 1980, Biogeographic history of Miocene Calcareous Nannoplankton and paleoceanography of the Atlantic Ocean: Micropaleontology, v.26, no.4, pp. 414-443

Hodell, D.A., Curtis, J.H., Sierro, F.J., and Raymo, M.E., 2001, Correlation of late Miocene to early Pliocene sequences between the Mediterranean and North Atlantic: Paleoceanography, v.16, pp. 164-178.

Hooker, J.J., Collinson, M.E., and Sille, N.P., 2004, Eocene-Oligocene mammalian faunal turnover in the Hampshire Basin, UK: Calibration to the global time scale and the major cooling event: Journal of the Geological Society, v.161, no.2, pp. 161-172. doi:10.1144/0016764903-091.

Hull, P.M., and Norris, R.D., 2011, Diverse patterns of ocean export productivity change across the Cretaceous-Paleogene boundary: New insights from biogenic barium: Paleoceanography, v.26, no.3, PA3205.

Katz, M.E., Miller, K.G., Wright, J.D., Wade, B.S., Browning, J.V., Cramer, B.S., and Rosenthal, Y., 2008, Stepwise transition from the Eocene greenhouse to the Oligocene icehouse: Nature Geoscience, v.1, no. 5, pp. 329-334. doi:10.1038/ngeo179.

Keller, G., and Lindinger, M., 1989, Stable isotope, TOC and $\mathrm{CaCO}_{3}$ record across the Cretaceous/Tertiary boundary at El Kef, Tunisia: Palaeogeography, Palaeoclimatology, Palaeoecology, v.73, nos. 3-4, pp. 243-265.

Keller, G., Adatte, T., Pardo, A., Bajpai, S., Khosla, A., and Samant, B., 2010, Cretaceous extinctions: Evidence overlooked: Science, v.328, no.5981, pp. 974-975.

Keller, G., Adatte, T., Stinnesbeck, W., Affolter, M. Schilli, L., and LopezOliva, J.G., 2002, Multiple Spherule Layers in the late Maastrichtian of northeastern Mexico: Geological Society of America Special Paper 356, pp. 145-161.

Kennett, J.P., and Shackleton, N.J., 1976, Oxygen isotopic evidence for the development of the psychrosphere $38 \mathrm{Myr}$ ago: Nature, v.260, no. 5577 , pp. 513-515.

Kennett, J.P., and Stott, L.D., 1991, Abrupt deep-sea warming, palaeoceano-graphic changes and benthic extinctions at the end of the Palaeocene: Nature, v.353, no.6341, pp. 225-229, doi: 10.1038/353225a0.

Kent, D.V., 1977, An estimate of the duration of the faunal change at the Cretaceous/Tertiary boundary: Geology, v.5, no.12, pp. 769-771.

Koch, P.L., Zachos, J.C., and Gingerich, P.D., 1992, Correlation between isotope records in marine and continental carbon reservoirs near the Palaeocene/Eocene boundary: Nature, v.358, no.6384, p. 319-322

Kyte, F.T., Smit, J., and Wasson, J.T., 1985, Siderophile interelement variations in the Cretaceous-Tertiary boundary sediments from Caravaca, Spain: Earth and Planetary Science Letters, v.73, no.2, pp. 183-195.

Landman, N.H., Johnson, R.O., Garb, M.P., Edwards, L.E., and Kyte, F.T., 2007, Cephalopods from the Cretaceous/Tertiary boundary interval on the Atlantic Coastal Plain, with a description of the highest ammonite zones in North America. Part 3, Manasquan River Basin, Monmouth
County, New Jersey: Bulletin of the American Museum of Natural History, v.303, pp. 1-122.

Larsen, H.C., Saunders, A.D., Clift, P.D., Beget, J., Wei, W., Spezzaferri, S., and Leg, O.D.P., 1994, Seven million years of glaciation in Greenland: Science, v.264, no.5161, pp. 952-955.

Lisiecki, L.E., and Raymo, M.E., 2005, A Pliocene-Pleistocene stack of 57 globally distributed benthic $\delta^{18} \mathrm{O}$ records: Paleoceanography, v.20, PA1003. doi:10.1029/2004PA001071

Luterbacher, H.P., and Premoli Silva, I., 1964, Biostratigrafia del limite Cretaceo-Terziario nell' Appennino central: Rivista Italiana di Paleontologia e Stratigrafia, v.70, no.67, pp. 67-88.

Magioncalda, R., Dupuis, C., Smith, T., Steurbaut, E., and Gingerich, P.D., 2004, Paleocene-Eocene carbon isotope excursion in organic carbon and pedogenic carbonate: Direct comparison in a continental stratigraphic section: Geology, v.32., no.7, pp. 553-556.

Marino, M., and Flores, J.A., 2002, Miocene to Pliocene calcareous nannofossil biostratigraphy at ODP Leg 177 Sites 1088 and 1090: Marine Micropaleontology, v.45, no.3, pp. 291-307.

McInerney, F.A., and Wing, S.L., 2011, The Paleocene-Eocene Thermal Maximum: A perturbation of carbon cycle, climate, and biosphere with implications for the future: Annual Review of Earth and Planetary Sciences, v.39, pp. 489-516.

Miller, K.G., Aubry, M.-P., Khan, J., Melillo, A.J., Kent, D.V., and Berggren, W.A., 1985, Oligocene-Miocene biostratigraphy, magnetostratigraphy, and isotopic stratigraphy of the western North Atlantic: Geology, v.13, no.4, pp. 257-261.

Miller, K.G., Fairbanks, R.G., and Mountain, G.S., 1987, Tertiary oxygen isotope synthesis, sea level history, and continental margin erosion: Paleoceanography, v.2, no.1, pp. 1-19.

Miller, K.G., Feigenson, M.D., Kent, D.V., and Olsson, R.K., 1988, Upper Eocene to Oligocene isotope $\left({ }^{87} \mathrm{Sr} /{ }^{86} \mathrm{Sr}, \mathrm{d}^{18} \mathrm{O}, \mathrm{d}^{13} \mathrm{C}\right)$ standard section, Deep Sea Drilling Project Site 522: Paleoceanography, v.3, no.2, pp. 223-233.

Miller, K.G., Wright, J.D., and Fairbanks, R.G., 1991, Unlocking the ice house: Oligocene-Miocene oxygen isotopes, eustasy, and margin erosion: Journal of Geophysical Research, v.96, no.B4, p. 6829-6848.

Miller, K.G., Kominz, M.A., Browning, J.V., Wright, J.D., Mountain, G.S., Katz, M.E., Sugarman, P.J., Cramer, B.S., Christie-Blick, N., and Pekar, S.F., 2005, The Phanerozoic record of global sea-level change: Science, v.310, no.5752, pp. 1293-1298.

Miller, K.G., Browning, J.V., Aubry, M.-P., Wade, B.S., Katz, M.E., Kulpecz, A.A., and Wright, J.D., 2008, Eocene-Oligocene global climate and sea-level changes: St. Stephens Quarry, Alabama: Geological Society of America Bulletin, v.120, nos.1-2, pp. 34-53. doi: 10.1130/B26105.1

Miller, K.G., Sherrell, R.M., Browning, J.V., Field, M.P., Gallagher, W., Olsson, R.K., Sugarman, P.J., Tuorto, S., and Wahyudi, H., 2010, Relationship between mass extinction and Iridium across the Cretaceous/ Paleogene boundary in New Jersey: Geology, v.38, no.10, pp. 867870. doi: 10.1130/G31135.1, Data Repository item 2010244.

Mitchum, R.M., Vail, P.R., and Thompson, S., 1977, The depositional sequence as a basic unit for stratigraphic analysis: American Association of Petroleum Geologists Memoir, v.26, p. 53-62.

Molina, E., Alegret, L., Arenillas, I., and Arz, J.A., 2005, The Cretaceous/ Paleogene boundary at the Agost section revisited: paleoenvironmental reconstruction and mass extinction pattern: Journal of Iberian Geology, v.31, no.1, pp. 135-148.

Molina, E., Alegret, L., Arenillas, I., Arz, J.A., Gallala, N., Hardenbol, J., Salis, K.V., Steurbaut, E., Vandenberghe, N., and Zaghbib-Turki, D., 2006, The global boundary stratotype section and point for the base of the Danian Stage (Paleocene, Paleogene, "Tertiary", Cenozoic) at El Kef, Tunisia-Original definition and revision: Episodes, v.29, no.4, pp. 263-273.

Odin, G.S., Guise, P., Rex, D.C., and Kreuzer, H., 1988, K-Ar and ${ }^{39} \mathrm{Ar} /$ ${ }^{40} \mathrm{Ar}$ geochronology of late Eocene biotites from the northeastern 
Apennines, in Premoli-Silva, I., Coccioni, R., and Montanari, A., eds., The Eocene-Oligocene boundary in the Marche-Umbria Basin (Italy): International Sub-commission Paleogene Stratigraphy, Eocene/Oligocene Boundary Meeting, Ancona, Oct. 1987, Special Publication, pp. 239-245.

Olsson, R.K., Miller, K.G., Browning, J.V., Habib, D., and Sugarman, P.J., 1997, Ejecta layer at the Cretaceous-Tertiary boundary, Bass River, New Jersey (Ocean Drilling Program Leg 174AX): Geology, v.25, no.8, pp. 759-762.

Olsson, R.K., Miller, K.G., Browning, J.V., Wright, J.D., and Cramer, B.S., 2002, Sequence stratigraphy and sea-level change across the Cretaceous-Tertiary boundary on the New Jersey passive margin: Geological Society of America Special Paper 356, pp. 97-108.

Pearson, P.N., McMillan, I.K., Wade, B.S., Dunkley Jones, T., Coxall, H.K., Bown, P.R., and Lear, H.L., 2013, Extinction and environmental change across the Eocene-Oligocene boundary in Tanzania: Geology, v.36, pp. 179-182.

Pomerol, C., and Premoli-Silva, I., 1986, The Eocene-Oligocene transition: Events and boundary, in Pomerol, C., and Premoli-Silva, I., eds., Terminal Eocene events: Elsevier, New York, pp. 1-24.

Poore, R.Z., Tauxe, L., Percival, Jr., S.F., and Labrecque, J.L., 1982, Late Eocene-Oligocene magnetostratigraphy and biostratigraphy at South Atlantic DSDP site 522: Geology, v.10, no.10, pp. 508-511.

Premoli-Silva, I., Orlando, M., Monecchi S., Madile, M., Napoleone, F., and Ripepe, M., 1988, Calcareous plankton biostratigraphy and magnetostratigraphy at the Eocene-Oligocene transition in the Gubbio area, in Premoli-Silva, I., Coccioni R., and Montanari, A., eds., The Eocene-Oligocene Boundary in the Marche-Umbria Basin (Italy): Ancona, Italy, International Subcommission on Paleogene Stratigraphy, International Union of Geological Sciences (IUGS) Commission o f Stratigraphy, pp. 137-161.

Raup, D.M., and Sepkoski, J.J., 1982, Mass extinctions in the marine fossil record: Science, v.215, no.4539, pp. 1501-1503.

Reilly, T.J., Miller, K.G., and Feigenson, M.D., 2002, Late Eocene to Oligocene Sr-isotopic reference section, Site 522, eastern South Atlantic: Paleoceanography, v.18, no.1, pp. 1-9.

Renne, P.R., Deino, A.L., Hilgen, F.J., Kuiper, K.F., Mark, D.F., Mitchell, W.S., Morgan, L.E., Mundil, R., and Smit, J., 2013, Time scales of critical events around the Cretaceous-Paleogene boundary: Science, v.339, no.6120, pp. 684-687.

Richards, M.A., Alvarez, W., Self, S., Karlstrom, L., Renne, P.R., Manga, M., Sprain, C.J., Smit, J., Vanderkluysen, L., and Gibson, S.A., 2015, Triggering of the largest Deccan eruptions by the Chicxulub impact: Geological Society of America Bulletin, v.127, nos.11-12, pp. 15071520 .

Rio, D., Sprovieri, R., Castradori, D., and Di Stefano, E., 1998, The Gelasian Stage (Upper Pliocene): a new unit of the global standard chronostratigraphic scale: Episodes, v.21, pp. 82-87.

Robin, E., and Rocchia, R., 1998, Ni-rich spinel at the Cretaceous-Tertiary boundary of El Kef, Tunisia: Bulletin de la Société Geologique de France, v. 169 , no.3, pp. 365-372.

Röhl, U., Westerhold, T., Bralower, T.J., and Zachos, J.C., 2007, On the duration of the Paleocene-Eocene thermal maximum (PETM): Geochemistry, Geophysics, Geosystems, v.8, no.12, pp. 1-13.

Salvador, A. (ed.), 1994, International stratigraphic guide: a guide to stratigraphic classification, terminology, and procedure. No. 30: Geological Society of America, $206 \mathrm{pp}$.

Savin, S.M., Douglas, R.G., and Stehli, F.G., 1975, Tertiary marine paleotemperatures: Geological Society of America Bulletin, v.86, no.11, pp. 1499-1510

Sawlowicz, Z., 1993, Iridium and other platinum-group elements as geochemical markers in sedimentary environments: Palaeogeography, Palaeoclimatology, Palaeoecology, v.104, no.1, pp. 253-270.

Schmitz, B., Pujalte, V., Molina, E., Monechi, S., Orue-Etxebarria, X., Speijer, R.P., Alegret, L., Apellaniz, E., Arenillas, I., Aubry, M.-P., and
Baceta, J.I., 2011, The global stratotype sections and points for the bases of the Selandian (Middle Paleocene) and Thanetian (Upper Paleocene) stages at Zumaia, Spain: Episodes, v.34, no.4, pp. 220-243.

Schulte, P., Alegret, L., Arenillas, I., and 38 others, 2010, The Chicxulub asteroid impact and mass extinction at the Cretaceous-Paleogene boundary: Science, v.327, no.5970, pp. 1214-1218. DOI: $10.1126 /$ science. 1177265 .

Shackleton, N.J., and Opdyke, N.D., 1973, Oxygen isotopic and palaeomagnetic stratigraphy of equatorial Pacific piston core V28-238: Oxygen isotope temperatures and ice volume on a 105 and 106 year scale: Quaternary Research, v.3, no.1, pp. 39-55.

Shackleton, N.J., and 16 others, 1984, Oxygen isotope calibration of the onset of ice-rafting and history of glaciation in the North Atlantic region: Nature, v.307, pp. 620-623.

Shackleton, N.J., Hall, M.A., Raffi, I., Tauxe, L., and Zachos, J., 2000, Astronomical calibration age for the Oligocene-Miocene boundary: Geology, v.28, no.5, pp. 447-450.

Snyder, S.W., Müller, C., and Miller, K.G., 1985, Eocene-Oligocene boundary: Biostratigraphic recognition and gradual paleoceanographic change at DSDP Site 549: Geology, v.12, no.2, pp. 112-115.

Sprain, C.J., Renne, P.R., Wilson, G.P., and Clemens, W.A., 2014, Highresolution chronostratigraphy of the terrestrial Cretaceous-Paleogene transition and recovery interval in the Hell Creek region, Montana: Geological Society of America Bulletin, v.127, nos.3-4, pp. 393-409. doi:10.1130/B31076.1

Steininger, F.F., Aubry, M.P., Berggren, W.A., Biolzi, M., Borsetti, A.M., Cartlidge, J.E., Cati, F., Corfield, R., Gelati, R., Iaccarino, S., and Napoleone, C., 1997, The global stratotype section and point (GSSP) for the base of the Neogene: Episodes, v.20, pp. 23-28.

St. John, K., 2008, Cenozoic ice-rafting history of the central Arctic Ocean: Terrigenous sands on the Lomonosov Ridge: Paleoceanography, v.23, PA1S05. doi:10.1029/2007PA001483.

Swisher, C.C., III, Wang, X., Zhou, Z., Wang, Y., Jin, F., Zhang, J., Xu, X., Zhang, F., and Wang, Y., 2002, Further support for a Cretaceous age for the feathered dinosaurs of Liaoning, China: New ${ }^{40} \mathrm{Ar} /{ }^{39} \mathrm{Ar}$ dating of the Yixian and Tuchengzi formations: Chinese Science Bulletin, v.47, no.2, pp. 135-137.

Tauxe, L.P., and Hartl, P., 1997, 11 million years of Oligocene geomagnetic field behavior: Geophysical Journal International, v.128, no.1, pp. 217-229.

Toon, O.B., Pollack, J.B., Ackerman, T.P., Turco, R.P., McKay, C.P., and Liu, M.S., 1982, Evolution of an impact-generated dust cloud and its effects on the atmosphere: Geological Society of America Special Paper, v.190, pp. 187-200.

Thomas, D.J., Zachos, J.C., Bralower, T.M., Thomas, E., and Bohaty, S., 2002, Warming the fuel for the fire: Evidence for the thermal dissociation of methane hydrate during the Paleocene-Eocene thermal maximum: Geology, v.30, no.12, pp. 1067-1070.

Vail, P.R., Mitchum, R.M., Jr., and Thompson, S., III, 1977, Seismic stratigraphy and global changes of sea level, part 4: global cycles of relative changes of sea level: American Association of Petroleum Geologists Memoir, v.26, pp. 83-97.

Vellekoop, J., Esmeray-Senlet, S., Miller, K.G., Browning, J.V., Sluijs, A., van de Schootbrugge, B., Sinninghe Damsté, J.S., and Brinkhuis, H., in press, Unequivocal evidence for Cretaceous-Paleogene boundary bolide 'impact winter' conditions from New Jersey, USA: Geology.

Wade, B.S. and Pearson, P.N., 2008, Planktonic foraminiferal turnover, diversity fluctuations and geochemical signals across the Eocene/Oligocene boundary in Tanzania: Marine Micropaleo., v.68, p. 244-255.

Wade, B.S., Pearson, P.N., Berggren, W.A., and Pälike, H., 2011, Review and revision of Cenozoic tropical planktonic foraminiferal biostratigraphy and calibration to the geomagnetic polarity and astronomical time scale: Earth Science Reviews, v.104, no.1, pp. 111-142.

Walker, M., Johnsen, S., Rasmussen, S.O., Popp, T., Steffensen, J.P., Gibbard, P., Hoek, W., Lowe, J., Andrews, J., Björck, S., and Cwynar, L.C., 
2009, Formal definition and dating of the GSSP (Global Stratotype Section and Point) for the base of the Holocene using the Greenland NGRIP ice core, and selected auxiliary records: Journal of Quaternary Science, v.24, no.1, pp. 3-17.

Wolf-Welling, T.C.W., Cremer, M., O'Connell, S., Winkler, A., and Thiede, J., 1996, Cenozoic Arctic gateway paleoclimate variability: Indications from changes in coarse-fraction composition, in Thiede, J. et al., eds., Proceeding of the Ocean Drilling Program, Scientific Results, v.151, pp. 515-567.

Wright, J.D., and Miller, K.G., 1992, Miocene stable isotope stratigraphy, Site 747, Kerguelen Plateau, in Wise, S.W., Jr., Schlich, R. et al., eds., Proceedings of the Ocean Drilling Program, Scientific Results, Volume 120, Part B: College Station, Texas, Ocean Drilling Program, pp. $855-866$.

Wright, J.D., and Schaller, M.F., 2013, Evidence for a rapid release of carbon at the Paleocene-Eocene thermal maximum: Proceedings of the National Academy of Sciences of the United States of America, v.110, no.40, pp. 15908-15913.

Yancey, T.E., and Guillemette, R.N., 2008, Carbonate accretionary lapilli in distal deposits of the Chicxulub impact event: Geological Society of America Bulletin, v.120, nos.9-10, pp. 1105-1118. doi: 10.1130/B26146.1

Zachos, J.C., Breza, J., and Wise, S.W., 1992, Earliest Oligocene ice-sheet expansion on East Antarctica: Stable isotope and sedimentological data from Kerguelen Plateau: Geology, v.20, p. 569-573.

Zachos, J.C., Lohmann, K.C., Walker, J.C.G., and Wise, S.W., 1993, Abrupt climate change and transient climates in the Paleogene: A marine perspective: Journal of Geology, v.100, p. 191-213.

Zachos, J.C., Quinn, T.M., and Salamy, S., 1996, High resolution ( $10^{4}$ yr $)$ deep-sea foraminiferal stable isotope records of the earliest Oligocene climate transition: Paleoceanography, v.9, no.3, pp. 353-387.

Zachos, J.C., Pagani, M., Sloan, L., Thomas, E., and Billups, K., 2001, Trends, rhythms, and aberrations in global climate 65 Ma to present: Science, v.292, no.5517, pp. 686-693.

Zanazzi, A., Kohn, J.J., MacFadden, B.J., and Terry, Jr., D.O., 2007, Large temperature drop across the Eocene-Oligocene transition in central North America: Nature, v.445, no.7128, pp. 639-642.

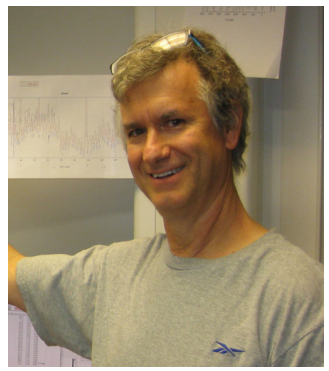

James D. Wright is a Professor in the Department of Earth and Planetary Sciences at Rutgers University. He earned a B.S. in Mathematics and Physics from Ouachita Baptist University (1982), a B.S. in Geology from Louisiana Tech University (1984), a M.S. in Geology from the University of South Carolina (1986), and a Ph.D. from Columbia University (1991). He was a Post-Doctoral and Associate Research Scientist at Lamont-Doherty Earth Observatory from 1991-1994 and an Assistant Professor at the University of Maine, Orono from 1994-1998. He established the Stable Isotope Lab at Rutgers University in 1988. His primary field of expertise is the relationship of deep-water circulation and climate change with an interest in ocean gateways. As the Director of the Stable isotope Lab, he has collaborated on diverse projects that span the last 250 million years reconstructing atmospheric $\mathrm{pCO}_{2}$ associated with large igneous provinces to paleo-environmental reconstruction of the East African lakes. He has sailed on 9 scientific cruises, working on tropical carbonates in the Maldives and Bahamas and the high latitudes of Baffin Bay and Cape Farewell, Greenland. He is no stranger to provocative ideas, offering an alternative view of the onset of the Paleocene-Eocene Thermal Maximum (Wright and Schaller, 2013 and Schaller et al., 2016). 